\title{
Experimental and analytical model studies on leachate volume computation from solid waste
}

\author{
D. Sivakumar
}

Received: 18 November 2011/Accepted: 14 June 2012/Published online: 11 July 2012

(c) CEERS, IAU 2012

\begin{abstract}
An extensive use of solid-waste landfills for disposal of municipal and industrial wastes have prompted increased attention to groundwater pollution caused by leachate generated in such landfills. The potential for groundwater contamination by leachate has necessitated engineering designs for landfills. The quantity of leachate generated from the solid waste and the movement of water through the solid waste depends on water input and the solid-waste characteristics. This paper dealt with the experimental investigations using the laboratory solidwaste leaching column to estimate the total leachate volume/leachate flow for unsaturated and saturated conditions. The hydraulic properties of the solid waste like initial moisture content, field capacity, permanent wilting point, saturation moisture content, effective void ratio, saturation hydraulic conductivity and saturation suction pressure were determined from the small-scale laboratory experiments, which are the input for analytical model study of leachate flow/total leachate volume for both unsaturated and saturated conditions. The result of analytical model study was compared with the results of experimental investigations. Comparisons of measured and computed total leachate volume/leachate flow using Darcy's law showed reasonable agreement.
\end{abstract}

Keywords Landfill leachate - Unsaturated flow · Saturated flow $\cdot$ Analytical model $\cdot$ Darcy's law . Reynolds number

\footnotetext{
D. Sivakumar $(\square)$

Department of Civil Engineering, Vel Tech High Tech Dr. Rangarajan Dr. Sakunthala Engineering College, Affiliated to Anna University, \#60, Avadi Vel Tech Road, Vellanur, Avadi, Chennai 600062, Tamil Nadu, India e-mail: sivakumar.ijest@gmail.com
}

\section{Introduction}

Landfill is one of the most common methods for disposal of municipal solid waste around the world (El-Fadel et al. 1997; Abdulhussain et al. 2009). Municipal solid waste includes wastes which are generated from residential, commercial, industrial and institutional sectors (Pankaj and Prakash 2011). After land filling, solid waste undergoes physico-chemical and biological changes (Ehrig 1984), and when the percolating water such as rain fall, irrigation and moisture content of solid waste, the more contaminants in the form of liquid (leachate) are leached (Hamzeh et al. 2009) and landfill gases are evolved (Iaconi et al. 2006; Bicheldey and Latushkina 2010). The rate of generation of leachate and the time taken by leachate to reach the surface and groundwater bodies depend on the movement of leachate through the solid waste (Sivakumar 1999; Sivakumar and Thandaveswara 2004; Thandaveswara and Sivakumar 2004). Further, leachate contaminates the surface (Maqbool et al. 2011) and ground water (Mor et al. 2006; Aderemi Adeolu et al. 2011) bodies when it is mixed with them and threaten human health (Maqbool et al. 2011).

The composition of leachate depends on solid-waste compositions, operation mode of a landfill, climate and hydrogeological conditions (Yoshida et al. 2002; Slomczyńska and Slomczyński 2004; Bicheldey and Latushkina 2010), moisture, temperature, $\mathrm{pH}$, age of landfill (Kulikowska and Klimiuk 2008), biodegradable and nonbiodegradable carbon (Christensen and Bjerg 2001; Rodriguez et al. 2004), high chemical oxygen demand (COD) (Safari et al. 2011), biochemical oxygen demand (BOD), chloride and ammonia-nitrogen (Abdul Aziz et al. 2010; Saeedi et al. 2010), heavy metals (Ogundiran and Afolabi 2008; Kjeldsen et al. 2002; Christensen et al. 2001), organic salts (Oygard and Gjengedal 2009; Agatha 
and Nwabueze 2011) inorganic salts (Agamuthu and Al-Abdali 2009; Agatha and Nwabueze 2011), thickness and properties of soil covers, and the level of groundwater (Sivakumar 1999; Berhe et al. 2009).

The estimate of leachate rate in a landfill site is of considerable importance in the design of an appropriate collection system or the treatment alternatives (Zaman 2010) to reduce the offsite migration that might pollute surface water and groundwater resources (Ozturk et al. 2003). The characteristics and behaviour of unsaturated flow through solid waste from a municipal disposal facility were monitored in the laboratory-leaching column (Korfiatis et al. 1984). The movement of water through the solid waste is influenced by the solid-waste characteristics such as mass density and porosity (Zouboulis et al. 2004). The quality of leachate generated from the solid waste is affected by the composition of the materials such as organic and inorganic materials (Tchobanoglous et al. 1977; Todd 1980; Canter et al. 1987; Metcalf and Eddy 1993; Misra and Mani 1993).

A two dimensional, unsteady state moisture flow model "Flow Investigation for Landfill Leachate (FILL)" was used to describe the leachate flow (Korfiatis and Demetracopoulos 1986). FILL model used moisture routing; first through the soil cover and then through the under lying compacted solid waste. The formulation and solution techniques were also used to compute the leachate mound head in the saturated zone of a landfill (Demetracopoulos et al. 1984; Korfiatis and Demetracopoulos 1986; Demetracopoulos 1988). Further, the movement of contaminant from the landfill was analysed by a model using the moisture routing procedure (Remson et al. 1968; Perrier and Gibson 1980).

There are several models based on the water balance technique used to predict leachate quantity such as Hydrologic Evaluation of Landfill Performance (HELP) model (Schroeder et al. 1984), Leachate Production at Sanitary Landfill Sites (LPSLS) model (Dass et al. 1977) and Environmental Protection Agency (EPA) model (Fenn et al. 1975). A model was developed for designing of a system to collect leachate from a lined landfill site (Wong 1977). Further, a model was developed for designing landfill bottom liners, and this model dealt with the situation where in a relatively impermeable liner is overlaid by a highly permeable drainage layer (Demetracopoulos 1988). To describe the flow of leachate over and through the liners of solid-waste landfills, another three models (steady state, quasi steady state and transient state) were developed (Demetracopoulos et al. 1986). In this present study, experimental investigations have been carried out in the laboratory solid-waste leaching column of size $600 \times 600 \times 1,450 \mathrm{~mm}^{3}$ for obtaining the total leachate volume/leachate flow for unsaturated and saturated conditions of solid waste collected from the Solid Waste and Recycling Management unit (SWARM) at IIT Madras. An analytical model was also formulated for representing the total leachate quantity estimation using Darcy's law by considering the solid waste as homogeneous and porous medium where liquid moves vertically downwards. The hydraulic properties of the solid waste like initial moisture content $\left(\theta_{\mathrm{i}}\right)$, field capacity $\left(\theta_{\mathrm{f}}\right)$, permanent wilting point $\left(\theta_{\mathrm{r}}\right)$, saturation moisture content $\left(\theta_{\mathrm{s}}\right)$, saturation hydraulic conductivity $\left(K_{\mathrm{s}}\right)$ and saturation suction pressure $\left(\psi_{\mathrm{s}}\right)$ were determined from the small-scale laboratory experiments, which are the input for analytical computations of leachate volume/leachate flow for both unsaturated and saturated conditions. Further, the formulated analytical model results were compared with the results of experimental investigations to know how measured and computed leachate volume/leachate flow show reasonable agreement.

\section{Materials and methods}

\section{Experimental set-up}

The experimental set-up (Fig. 1) consists of a leaching column of size $600 \times 600 \times 1,450 \mathrm{~mm}^{3}$ (length $\times$ breadth $\times$ height) (Sivakumar 1999). The three sides of column (left, right and back sides) were built using brick masonry and the front side was fitted with Perspex sheet of $10-\mathrm{mm}$ thickness. The bottom RCC slab of a column was fitted with five outlets for draining the leachate and were indicated as bottom central (BC), bottom right (BR 1, BR 2) and bottom left (BL 1, BL 2) outlets. Five-side outlets fitted with control valves were centrally provided in left and right side walls of a column for draining the leachate. These were indicated as SL 1-SL 5 and SR 1-SR 5. The rainfall was simulated using nine nozzles of diameter $0.50 \mathrm{~mm}$, which was fitted in the bottom of aluminium water-holding tank of size $600 \times 600 \times 300 \mathrm{~mm}^{3}$ (Fig. 1). The water-holding tank was installed at the top of the leaching column and the head of $200 \mathrm{~mm}$ was provided/maintained to create a desired range of rainfall. The runoff collection (made of aluminium sheets of 2-mm thickness) channel $\left(100 \times 100 \mathrm{~mm}^{2}\right.$ in cross-section) was fitted around and at the top of the leaching column to collect runoff. Calibrated pressure transducers were used in recording the runoff with respect to time if there is outflow. Free drainage conditions at the bottom of the column were simulated by placing $100-\mathrm{mm}$ thick graded blue metal. To prevent the migration of the fine particles from the solid waste, a $100-\mathrm{mm}$ layer of sand of size ranging from 0.50 to $2.00 \mathrm{~mm}$ was placed over the gravel layer.

The solid waste collected from the dumping yard of IIT Madras was placed over these layers and manually 


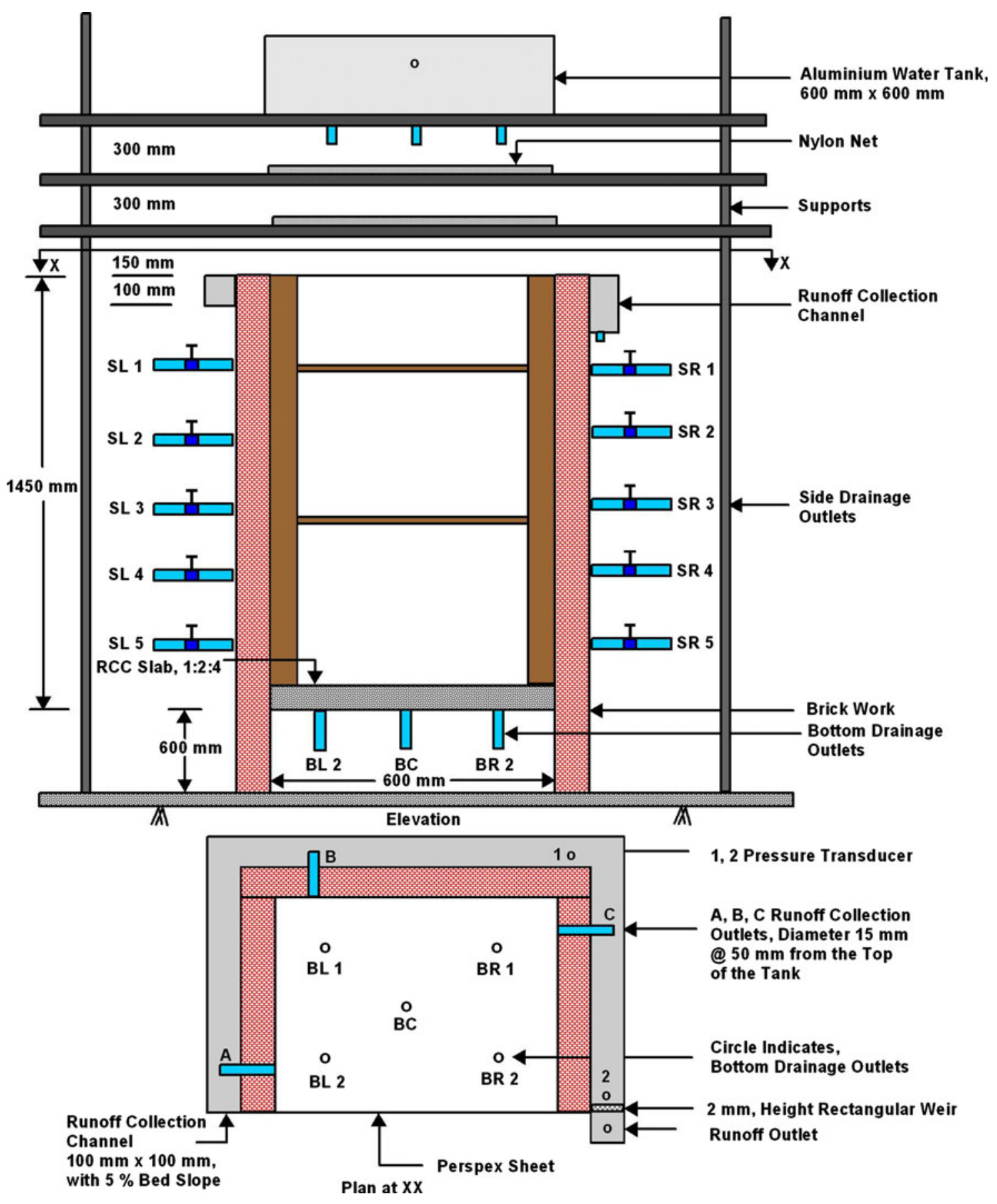

Fig. 1 Experimental set-up of solid-waste leachate column

compacted to attain a mass density of $2,420 \mathrm{~kg} / \mathrm{m}^{3}$, because the mass density of solid waste in the dumping yard (IIT Madras campus) was found to be $2,420 \mathrm{~kg} / \mathrm{m}^{3}$. The mass density of solid waste was calculated based on standard procedure (Murthy 1992; Ranjan and Rao 2000). The three solid-waste samples of $1 \mathrm{~kg}$ were collected from three places, viz., collected at centre, middle and boundary of IIT Madras dumping yard, respectively. The solid waste used for the experiments was estimated to be 4-month old. The composition of three representative solid-waste samples collected from IIT Madras dumping yard were determined at the time of samples collection and they were reported as percentage (i.e., reported as weight basis: ratio of weight of each component in the sample to the total weight of the sample). The composition details are given in Table 1. 
Table 1 Composition of representative solid waste from IIT Madras campus

\begin{tabular}{lrrrr}
\hline Components & $\begin{array}{l}\text { Sample } \\
(\%)\end{array}$ & $\begin{array}{l}\text { Sample 2 } \\
(\%)\end{array}$ & $\begin{array}{l}\text { Sample 3 } \\
(\%)\end{array}$ & $\begin{array}{l}\text { Average } \\
(\%)\end{array}$ \\
\hline Polythene milk sachets & 5.80 & 5.30 & 5.40 & 5.50 \\
Vegetable food wastes (organic) & 62.00 & 64.00 & 65.00 & 63.67 \\
Paper (news paper, card boards, etc.) & 3.80 & 5.20 & 5.00 & 4.67 \\
Wood chips (plant, carpentry) & 12.50 & 14.50 & 12.50 & 13.16 \\
Plastics (sheets, solid, bags, etc.) & 4.20 & 3.30 & 3.00 & 3.50 \\
Leather and rubber & 1.80 & 1.30 & 1.40 & 1.50 \\
Cotton wastes (thread, cloth, sanitary napkins, etc.) & 1.20 & 0.90 & 0.90 & 1.00 \\
Metals (aluminium, workshop waste, stainless & 0.60 & 0.35 & 0.55 & 0.50 \\
$\quad$ steel, pins, etc.) & & & & 2.80 \\
Glass & 2.30 & 1.80 & 3.45 & 4.20 \\
Others such as battery & 5.80 & 3.35 & 100.00 & 100.00 \\
Total & 100.00 & 100.00 & & \\
\hline
\end{tabular}

\section{Experimental combinations}

A total of 18 experimental combinations (runs) from R1 to R18 were conducted for two phases namely unsaturated and saturated conditions and are presented in Table 2. The movement of the water was controlled by operating either the side outlets or the bottom outlets and both bottom and side outlets and thus the main flow direction was assumed as horizontal, vertical and combination of these two, respectively. Two samples of filter media were selected (soil), one from IIT Madras campus another from Perungudi area (where a landfill site has been identified by Chennai Metro Corporation). The selection of filter media for this study is (1) to know the effect of filter media on generation of leachate volume, (2) to know the effect of selected thickness $(10 \mathrm{~cm})$ of filter media on generation of leachate volume and (3) to know the physico-chemical characteristics of leachate, before and after passing through the selected thickness of filter media (not discussed in this study).

The experimental observations for eighteen combinations are summarised in Tables 3 and 4. Table 3 indicates the general properties of solid waste collected. The experiments were carried out with uniform and constant rainfall intensity of $45 \mathrm{~mm} / \mathrm{h}$. Table 4 represents the total inflow, total outflow, total rainfall duration, total leachate collection duration, initial sorption of moisture by the solid waste and retained moisture in the solid waste for eighteen combinations. In this present study, the two combinations namely, R1 (US-BO-WO) and R2 (S-BO-WO) were presented in detail. Run $\mathrm{R} 1$ represents unsaturated, bottom outlet opened and without clay liner condition, and Run R2 represents saturated, bottom outlet opened and without clay liner condition. It may be noted that fresh three solid-waste samples collected from IIT Madras (SWARM) dumping yard were used to conduct the experiments of eighteen
Table 2 Summary of experimental combinations (runs)

\begin{tabular}{llll}
\hline Run nos. & Combinations & Run nos. & Combinations \\
\hline R1 & US-BO-WO & R10 & S-SO-WIL \\
R2 & S-BO-WO & R11 & US-BSO-WIL \\
R3 & US-SO-WO & R12 & S-BSO-WIL \\
R4 & S-SO-WO & R13 & US-BO-WPL \\
R5 & US-BSO-WO & R14 & S-BO-WPL \\
R6 & S-BSO-WO & R15 & US-SO-WPL \\
R7 & US-BO-WIL & R16 & S-SO-WPL \\
R8 & S-BO-WIL & R17 & US-BSO-WPL \\
R9 & US-SO-WIL & R18 & S-BSO-WPL \\
\hline
\end{tabular}

$U S$ unsaturated condition, $S$ saturated condition, $B O$ bottom outlets opened, $S O$ side outlets opened, $B S O$ both bottom and side outlets opened, WO without clay liner, WIL with IIT Madras clay liner, WPL with perungudi clay liner

combinations using a laboratory solid-waste leaching column and the initial moisture content of solid waste was found to be $24.10 \%$ (Modi 1995).

The hydraulic properties obtained from the small-scale laboratory experiments are the input for analytical computations of leachate flow for both unsaturated and saturated conditions. The experimental set-up consists of a small-scale cylindrical container of size 150.00-mm diameter, 250.00-mm height provided with bottom drainage outlets (fitted at the bottom of the container) of size $2.50 \mathrm{~mm}$. The solid waste of known moisture content was placed in this container and compacted at approximately the same density $\left(2,420 \mathrm{~kg} / \mathrm{m}^{3}\right)$ as in the leaching column. The suction pressure $(\psi)$ was measured corresponding to known moisture content $(\theta)$ using tensiometer. The same process was repeated for different moisture contents covering from full saturation moisture content $\left(\theta_{\mathrm{s}}\right)$ to lowest moisture content $\left(\theta_{\mathrm{r}}\right)$ of solid waste. The $\theta_{\mathrm{s}}$ was determined when the sample was brought to full saturation condition 


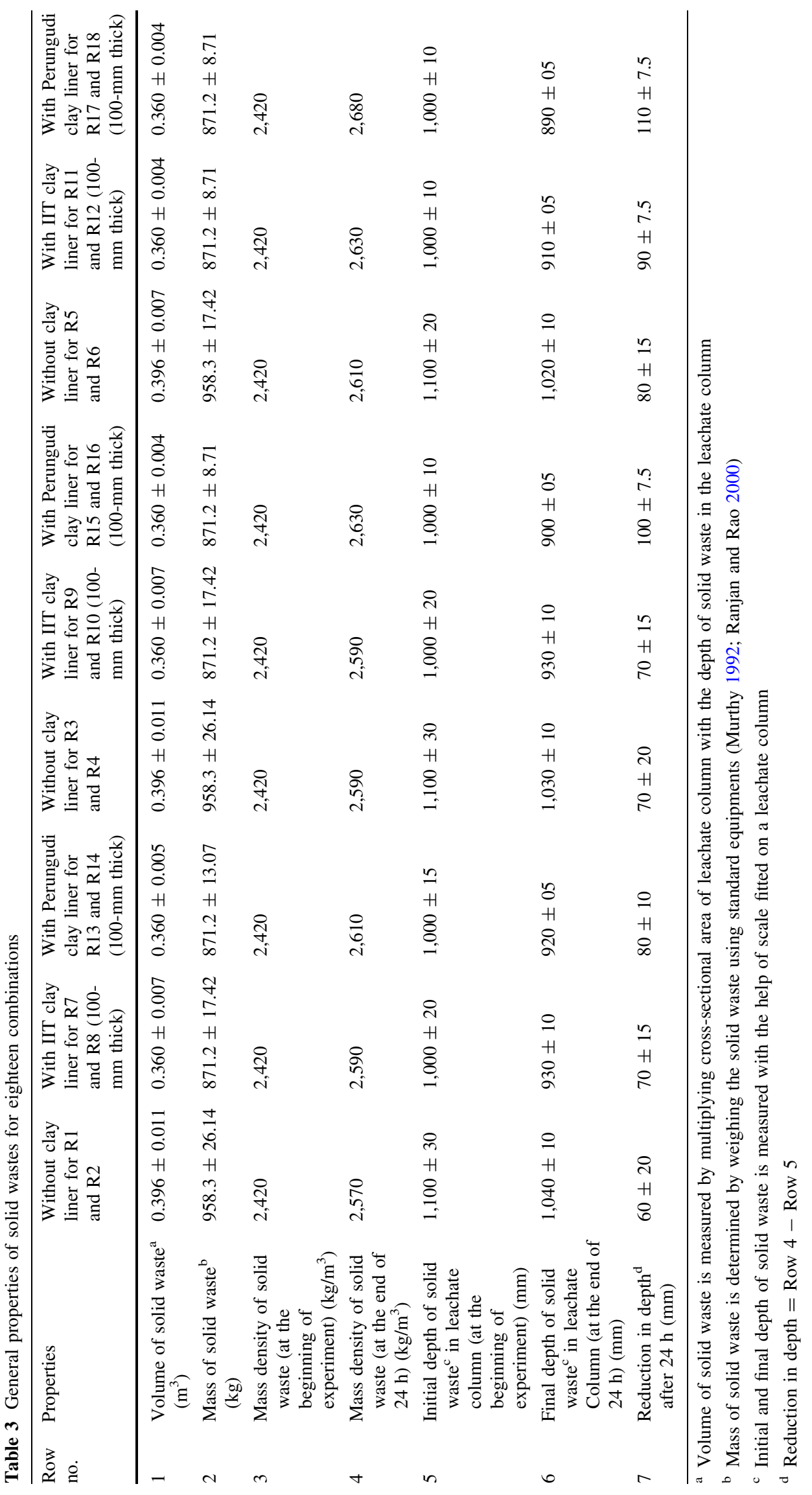




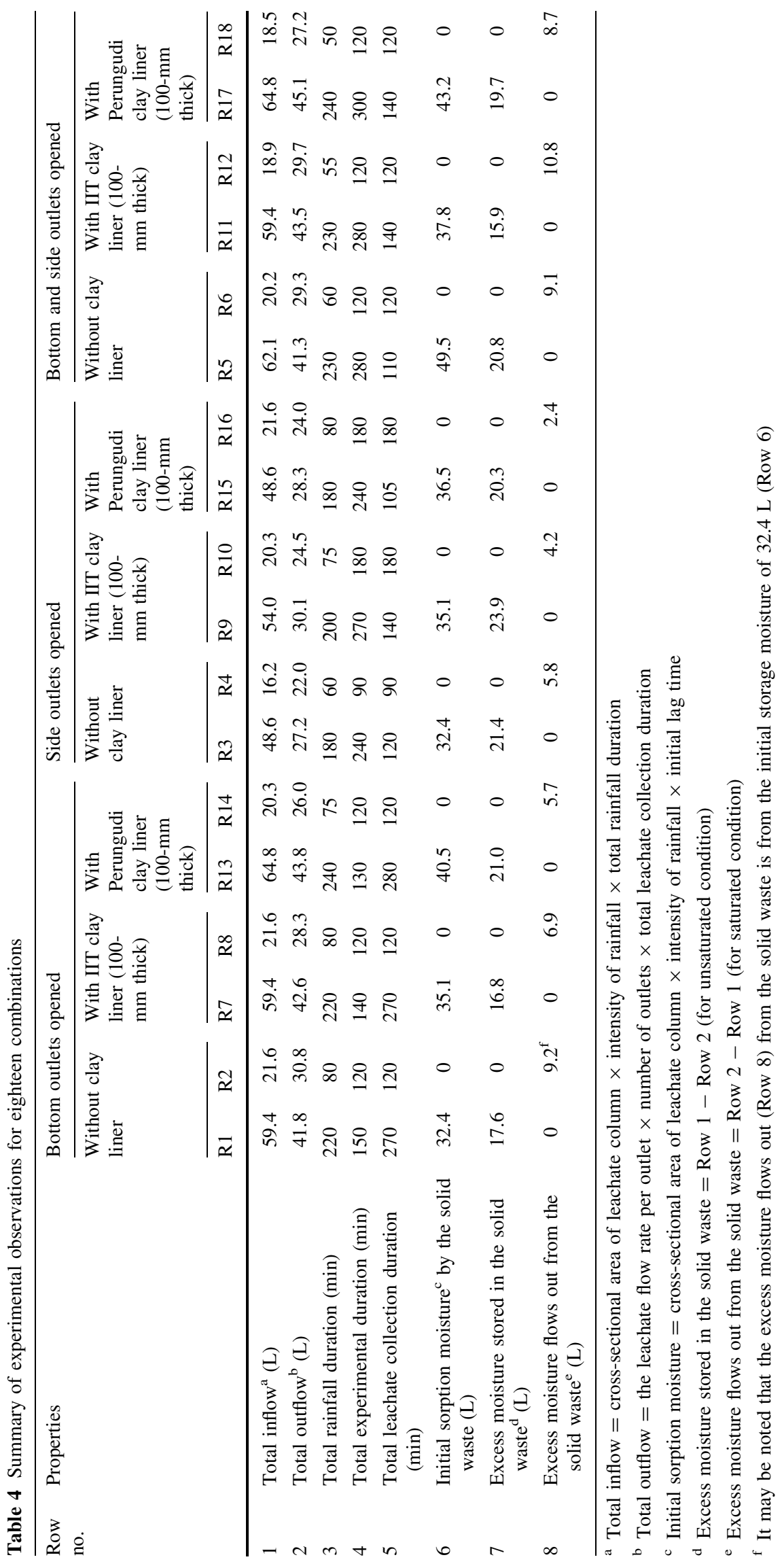


(by keeping bottom drain close). After finding the value of $\theta_{\mathrm{s}}$, the stored water in the sample was allowed to drain under gravity until the flow was ceased (by keeping bottom drain open), subsequently, the field capacity $\left(\theta_{\mathrm{f}}\right)$ and permanent wilting point $\left(\theta_{\mathrm{r}}\right)$ moisture contents were measured (Modi 1995).

Similarly, the saturation hydraulic conductivity $\left(K_{\mathrm{s}}\right)$ of solid waste was measured by conducting constant head permeability test using permeameter (Murthy 1992). The above various hydraulic properties were estimated by taking the average values of three solid-waste samples. From the experiments, the initial moisture contents $\theta_{\mathrm{i}}, \theta_{\mathrm{r}}, \theta_{\mathrm{f}}, \theta_{\mathrm{s}}$ and $K_{\mathrm{s}}$ were found to be 24.10, 10.70, 45.20, 56.50 and $160.90 \mathrm{~mm} / \mathrm{h}$, respectively. Similarly, the relationship between variation of suction pressure with moisture content (retention characteristics) was obtained (Demetracopoulos et al. 1984) based on experimental results and is shown in Fig. 2. The values of various hydraulic properties obtained were compared with the values obtained by earlier investigators and are given in Table 5.

\section{Results and discussion}

\section{Experimental study}

It may be observed from Table 3 , that the reduction in depth of solid-waste column after $24 \mathrm{~h}$ from the commencement of the experiment ranged between 60 and $110 \mathrm{~mm}$. Once the moisture content increased in solid waste, the dry or semi-dry materials in the solid waste will be swelled and very fine particles (organic matter) of solid waste is transported by the flowing water, thus filling of voids present in the solid waste is initiated. The degraded and decomposed contaminants in the solid waste are leached as liquid (Hamzeh et al. 2009) when solid waste undergoes physico-chemical and biological changes (Ehrig 1984) with increased moisture content by flowing water.

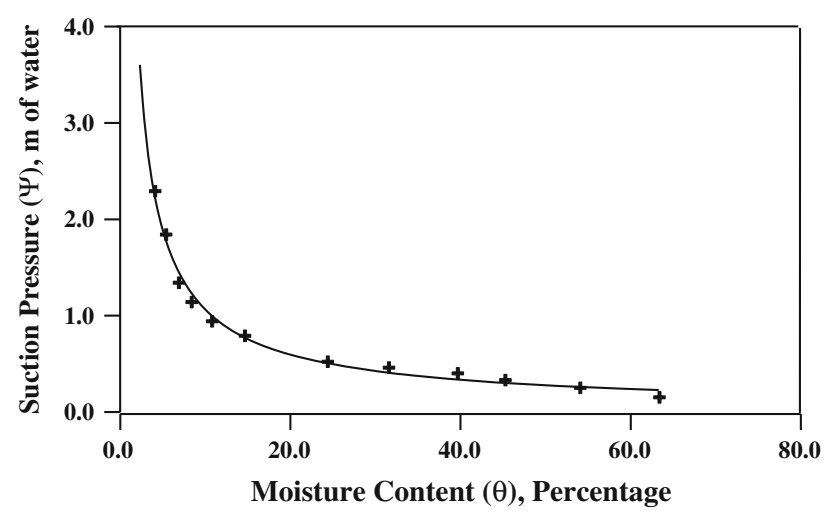

Fig. 2 Variation of suction pressure with moisture content
Table 5 Comparison of hydraulic properties of solid waste

\begin{tabular}{|c|c|c|c|}
\hline Parameters & $\begin{array}{l}\text { Present } \\
\text { study }\end{array}$ & $\begin{array}{l}\text { Korfiatis } \\
\text { et al. } \\
(1984)\end{array}$ & $\begin{array}{l}\text { Demetracopoulos } \\
\text { et al. (1984) }\end{array}$ \\
\hline $\begin{array}{l}\text { Initial moisture content } \\
\left(\theta_{\mathrm{i}}\right)(\%)\end{array}$ & 24.1 & 23.0 & - \\
\hline Field capacity $\left(\theta_{\mathrm{f}}\right)(\%)$ & 45.2 & 44.3 & 20.0 \\
\hline $\begin{array}{l}\text { Permanent wilting point } \\
\left(\theta_{\mathrm{r}}\right)(\%)\end{array}$ & 10.7 & 2.0 & - \\
\hline $\begin{array}{l}\text { Saturation moisture } \\
\text { content }\left(\theta_{\mathrm{s}}\right)(\%)\end{array}$ & 56.5 & 55.0 & 35.0 \\
\hline $\begin{array}{l}\text { Saturation hydraulic } \\
\text { conductivity }\left(K_{\mathrm{s}}\right) \\
(\mathrm{mm} / \mathrm{h})\end{array}$ & 160.9 & 457.2 & 7.62 \\
\hline $\begin{array}{l}\text { Saturation suction } \\
\text { pressure }\left(\psi_{\mathrm{s}}\right)(\mathrm{m} \text { of } \\
\text { water) }\end{array}$ & 0.10 & 0.062 & 0.35 \\
\hline $\begin{array}{l}\text { Solid-waste thickness } \\
(\Delta z)(\mathrm{mm})\end{array}$ & $1,100.0$ & $1,520.0$ & $6,100.0$ \\
\hline Constant $b$ & 2.27 & 1.5 & 7.0 \\
\hline Constant $B$ & $7.54^{\mathrm{a}}$ & $6.0^{\mathrm{a}}$ & $9.0^{\mathrm{b}}$ \\
\hline Rainfall rate $(\mathrm{mm} / \mathrm{h})$ & 45 & 31.75 & 8.87 \\
\hline
\end{tabular}

${ }^{\mathrm{a}} B=2 b+3$ (Korfiatis et al. 1984)

b Slope of characteristics curve plotted on log-log paper [relationship between $K(\theta)$ and $\theta$ ]

Further more, the generated biogas from solid waste is released into the atmosphere as a result of bio-decomposition of organic matter in the solid waste (Iaconi et al. 2006; Bicheldey and Latushkina 2010) by the incoming flowing water and temperature prevail within the solid waste. Due to the settlement of very fine organic matter within the solid waste, drained-out leachate from the solid waste and removal of biogas/air from the pores of the solid waste, self compaction/consolidation took place. The net effective result was the reduction of depth in a leaching column. The reduction in depth depends on size and nature of materials present in the solid waste.

Figure $3 \mathrm{a}-\mathrm{d}$ shows the hyetograph, cumulative rainfall and cumulative leachate volumes collected from the bottom drainage, without clay liner for unsaturated (R1) and saturated (R2) conditions. It may be observed from Fig. 3b that the initial outflow of leachate has a time lag of 120 min from the commencement of the experiment. The total volume of leachate collected from the bottom drainage at various outlets was $41.80 \mathrm{~L}$. The total volume of rainfall into the system was $59.40 \mathrm{~L}$ over the total rainfall duration of $220 \mathrm{~min}$. The experiment was continued up to 270 min from the commencement of the experiment and leachate collection was for the duration of $150 \mathrm{~min}$ (i.e., $270-120 \mathrm{~min}$ ).

The volume of water retained in filling the voids of solid-waste column was $17.60 \mathrm{~L}$ which is equal to the voids space. Thus, the volume of water retained by the 
(a)

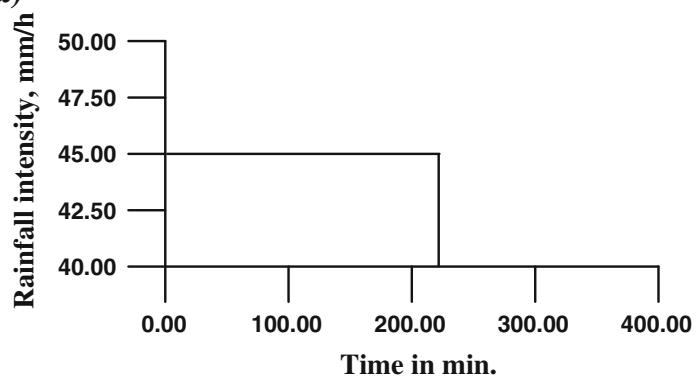

(b)

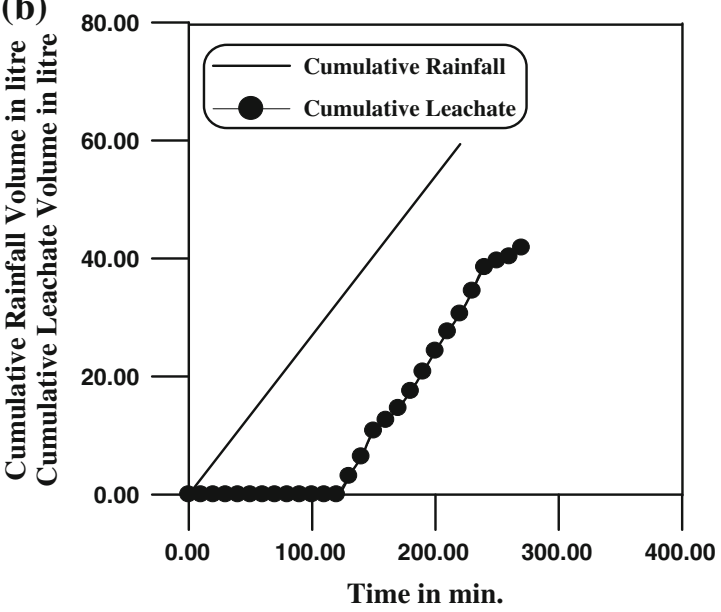

(c)

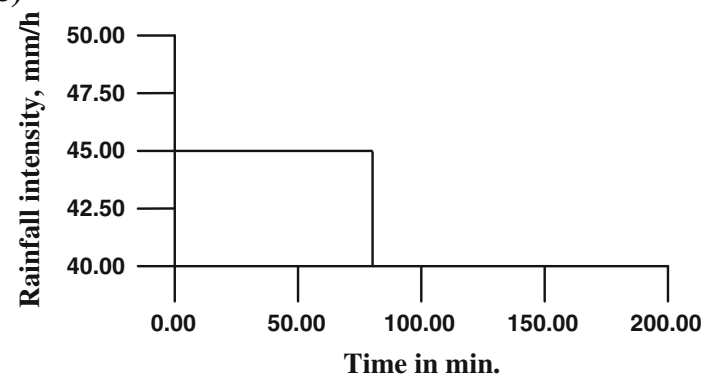

(d)

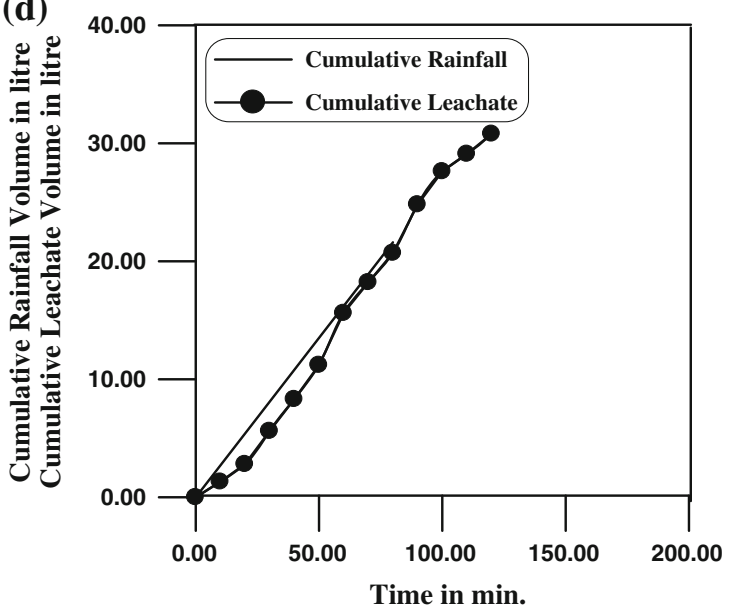

Fig. 3 a Hyetograph. b Cumulative rainfall and leachate volumes collected from bottom drainage-without clay liner, unsaturated condition (R1). c Hyetograph. d Cumulative rainfall and leachate volumes collected from bottom drainage-without clay liner, saturated condition (R2)

solid waste at any time step was the difference of the cumulative rainfall volume and cumulative leachate volume plus initial moisture content. The experimentally obtained initial moisture content of the unsaturated solid waste is $24.10 \%$. In the case of saturated condition, the experiments were carried out with the initial moisture content greater than the field capacity. This was achieved by adding water initially to the solid waste. The supply of water was then stopped as soon as ponding of water commences on the surface of the solid waste. This was taken as initial condition for the experiments for saturated condition. From Fig. 3d, it may be seen that the initial outflow of leachate occurred almost instantaneously and there was no lag time unlike in R1. The total volume of leachate collected from the bottom drainage at various outlets was found to be $30.80 \mathrm{~L}$. The total rainfall duration was $80 \mathrm{~min}$ with the total volume of input to the system was $21.60 \mathrm{~L}$. The total experimental duration for this condition and the leachate-collection duration were $120 \mathrm{~min}$ as in the previous situation.

Figure 4 shows the leachate hydrograph for unsaturated condition, without clay liner when all the bottom outlets viz., BL 1, BL 2, BR 1, BR 2 and $\mathrm{BC}$ were opened (R1). From Fig. 4, it may be observed that the time to peak discharges were different for different outlets, thus indicating the non-homogeneous distribution of voids. The flow path connectivity also varied. Further, no surface runoff observed as the measured saturation hydraulic conductivity was higher $(160.90 \mathrm{~mm} / \mathrm{h})$ than the precipitation intensity $(45.00 \mathrm{~mm} / \mathrm{h}$ ). During the initial period of $120 \mathrm{~min}$ (lag time), volume of water filled in the solid-waste column was $32.40 \mathrm{~L}$ (area $3,600.00 \mathrm{~mm}^{2} \times$ intensity $45.00 \mathrm{~mm} /$ $\mathrm{h} \times$ duration $2.00 \mathrm{~h}$ ). The increased retained moisture in the column during the period of continuous application of rainfall was due to the movement of the wetting front. The moisture content from saturated top layer migrated to lower one when it exceeded the field capacity. The time taken for reaching saturation and travel time of leachate in each slice of solid waste together contribute to the lag time. The difference between cumulative volumes of rainfall and leachate, at $270 \mathrm{~min}$ was only $17.60 \mathrm{~L}$. Thus, the difference in quantity of $14.80 \mathrm{~L}$ (i.e., $43.30 \%$ of initial storage water) was drained as leachate.

Figure 5 shows the leachate hydrograph for saturated condition, without clay liner when all the bottom outlets viz., BL 1, BL 2, BR 1, BR 2 and BC were kept opened (R2). It may be observed from the Fig. 5 that the time to peak discharge varied between 25 and $35 \mathrm{~min}$; whereas for 
Fig. 4 Leachate hydrographs when bottom drainage outlets are kept opened-without clay liner, unsaturated condition (R1). a Leachate from bottom left outlet (BL 1). b Leachate from bottom right outlet (BR 1). c Leachate from bottom centre outlet (BC). d Leachate from bottom left outlet (BL 2). e Leachate from bottom right outlet (BR 2)

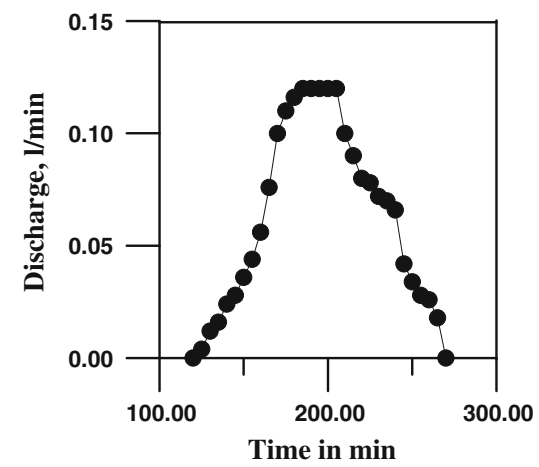

(a)

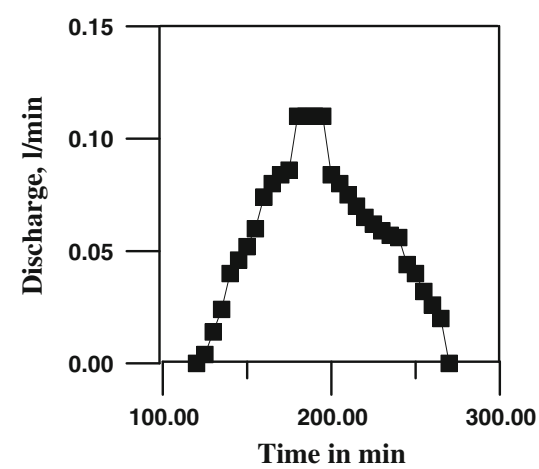

(b)

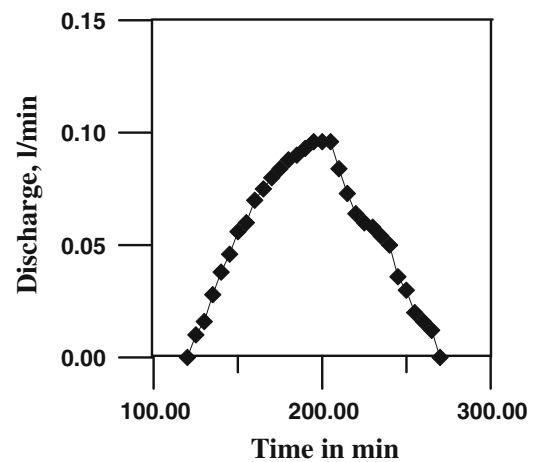

(c)

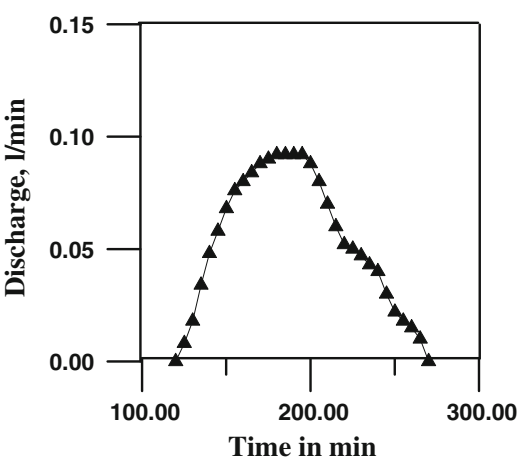

(d)

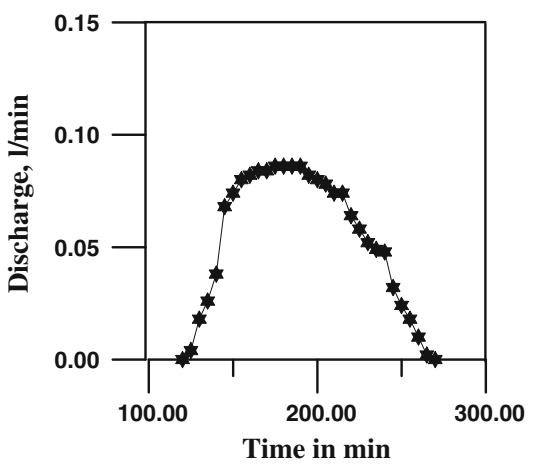

(e) the unsaturated condition, it ranged between 50 and $60 \mathrm{~min}$, and in saturated condition, the peak discharge values were not the same. Further, it may be observed from Fig. 5 that the outflow leachate volume was higher in saturated condition than the unsaturated condition (Fig. 4). It may also be noted from Table 4 that in case of saturated condition the amount of moisture content that gets added to the total outflow of $9.20 \mathrm{~L}(28.30 \%)$, which was from the initial storage moisture content of the solid waste (32.40 L).

\section{Analytical model study}

The solid waste used in the present study was treated as homogeneous and porous medium where liquid moves vertically downwards. The leachate flow may be obtained using Darcy's law (Demetracopoulos et al. 1984; Khanbilvardi et al. 1995), states that

$q=K(\theta)-D(\theta)(\partial \theta / \partial z)$

in which $q$ is leachate flow per unit area $\left[\mathrm{LT}^{-1}\right], K(\theta)$ is hydraulic conductivity $\left[\mathrm{LT}^{-1}\right], \quad D(\theta)$ is diffusivity coefficient $\left[\mathrm{L}^{2} \mathrm{~T}^{-1}\right]$ and $z$ is depth coordinate [L]. The parameters $K(\theta)$ and $D(\theta)$ are dependents on the moisture content $(\theta)$. Several theoretical and experimental relationship have been proposed for the determination of $K(\theta)$ and $D(\theta)$ (Demetracopoulos et al. 1984; Khanbilvardi et al. 1995; Korfiatis et al. 1984). For this study, the hydraulic conductivity $K(\theta)$ can be calculated by (Khanbilvardi et al. 1995), 
Fig. 5 Leachate hydrographs when bottom drainage outlets are kept opened-without clay liner, saturated condition (R2). a Leachate from bottom left outlet (BL 1). b Leachate from bottom right outlet (BR 1).

c Leachate from bottom centre outlet (BC). d Leachate from bottom left outlet (BL 2).

e Leachate from bottom right outlet (BR 2)

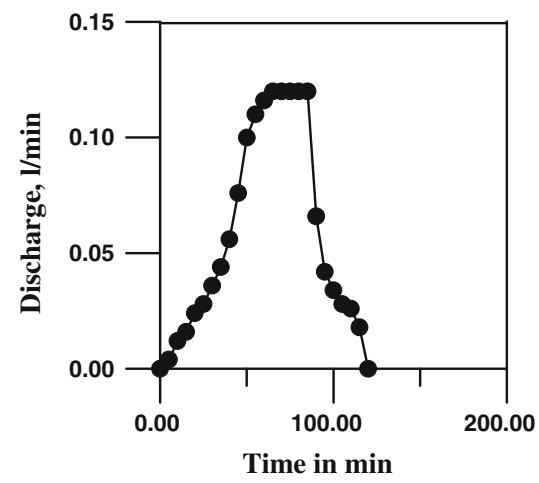

(a)

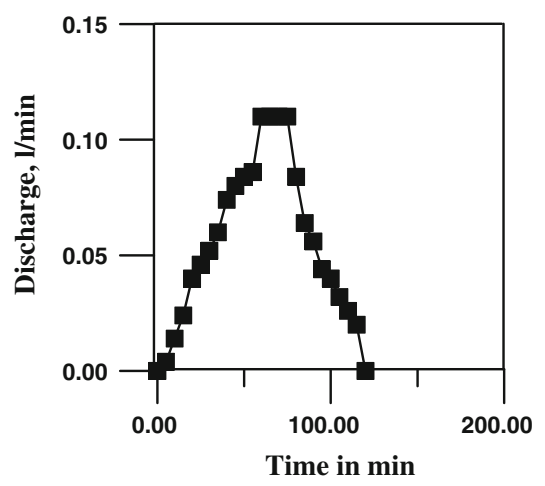

(b)

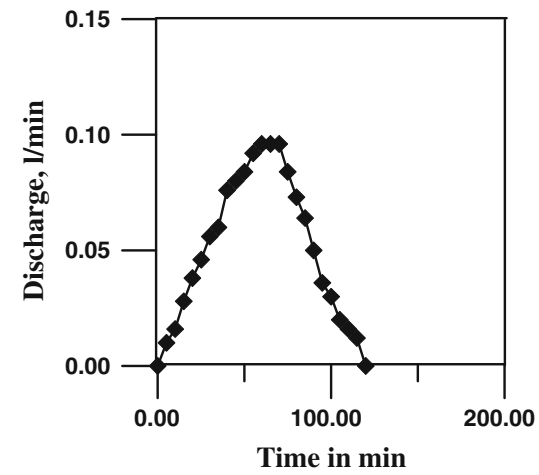

(c)

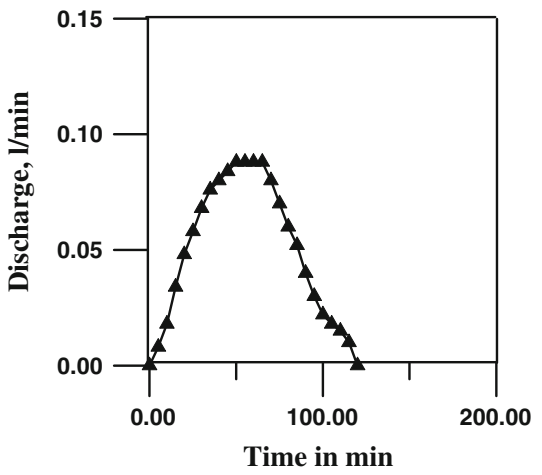

(d)

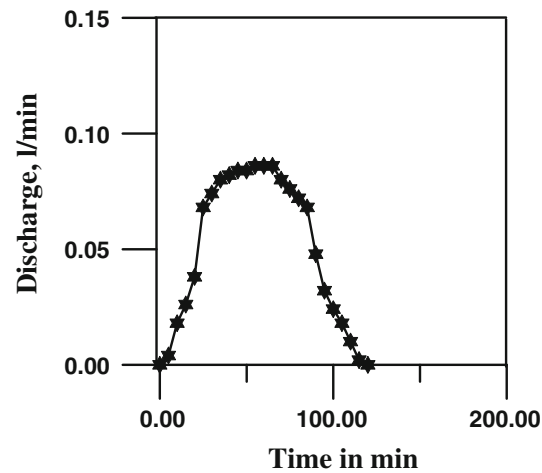

(e)
$K(\theta)=K_{\mathrm{s}}\left(\theta / \theta_{\mathrm{s}}\right)^{B}$

in which $\theta\left[\mathrm{L}^{3} \mathrm{~L}^{-3}\right]$ and $\theta_{\mathrm{s}}\left[\mathrm{L}^{3} \mathrm{~L}^{-3}\right]$ are the moisture content and saturation moisture content of solid waste, respectively, $K_{\mathrm{S}}$ is saturation hydraulic conductivity $\left[\mathrm{LT}^{-1}\right]$ and $B$ is a constant exponent is equal to $(2 b+3)$ (Campbell 1974; Khanbilvardi et al. 1995) in which $b$ is also a constant and it is estimated from the relation (Demetracopoulos et al. 1984; Korfiatis et al. 1984).

$\psi=\psi_{\mathrm{s}}\left(\theta / \theta_{\mathrm{s}}\right)^{-b}$

in which, $\psi$ is the suction head (L) and $\psi_{\mathrm{s}}$ is the saturation suction head or saturation suction pressure (L).
The Eq. (3) may be rewritten as

$$
\begin{aligned}
& \psi_{\mathrm{s}} / \psi=\left(\theta_{\mathrm{s}} / \theta\right)^{b} \quad \text { or } \\
& \log \left(\psi_{\mathrm{s}} / \psi\right)=b \log \left(\theta_{\mathrm{s}} / \theta\right) \quad \text { or } \\
& b=\log \left(\psi_{\mathrm{s}} / \psi\right) / \log \left(\theta_{\mathrm{s}} / \theta\right)
\end{aligned}
$$

Thus $b$ is determined from the experimental data and found to be 2.27. The diffusivity coefficient $D(\theta)$ corresponding to the moisture content of solid waste (Klute 1952; Khanbilvardi et al. 1995) is obtained by combination of Eqs. (2) and (3) and is given by

$D(\theta)=K(\theta)(\partial \psi / \partial \theta)$

in which $\partial \psi / \partial \theta$ can be calculated by 
$\partial \psi / \partial \theta=\left(\psi_{\mathrm{s}} / \theta_{\mathrm{s}}\right) b\left(\theta_{\mathrm{s}} / \theta\right)^{b+1}$

Substitute all the values in the Eq. (1), and Eq. (1) becomes

$q=K_{\mathrm{s}}\left(\theta / \theta_{\mathrm{s}}\right)^{2 b+3}-K(\theta)(\partial \psi / \partial \theta)(\partial \theta / \partial z) \quad$ or

$q=K_{\mathrm{s}}\left(\theta / \theta_{\mathrm{s}}\right)^{7.54}-K_{\mathrm{s}}\left(\theta / \theta_{\mathrm{s}}\right)^{7.54}\left(\psi_{\mathrm{s}} / \theta_{\mathrm{s}}\right) 2.27$ $\times\left(\theta_{\mathrm{s}} / \theta\right) 3.27(\partial \theta / \partial z)$ or

$q=K_{\mathrm{s}}\left(\theta / \theta_{\mathrm{s}}\right)^{7.54}\left[1-2.27\left(\psi_{\mathrm{s}} / \theta_{\mathrm{s}}\right)\left(\theta_{\mathrm{s}} / \theta\right)^{3.27}(\partial \theta / \partial z)\right]$

In this present study, Eq. (7), was used to determine the leachate flow per effective unit area generated from the solid waste at any sanitary landfill for unsaturated and saturated conditions. The values of various hydraulic properties (Table 5) and the suction pressure at any moisture content (Fig. 2) were used as input data for analytical model study [Eq. (7)].

Comparison of experimental and analytical model studies

The experimental results obtained from unsaturated and saturated (without clay liner) conditions were compared with that of the analytical model results. Figure 6 shows the measured and computed leachate volumes for unsaturated condition. As mentioned earlier, it may be noted that the volume of leachate collected from the solid waste through bottom outlets started after the $120 \mathrm{~min}$ from the commencement of experiment for both the model and experiment. It may be also observed from Fig. 6 that the rising limb of leachate hydrograph of computed leachate was almost matching with the experimental results. But in the recession limb portion of hydrograph, the computed leachate volume was less than the experimental observation. The measured volume of leachate was $42.00 \mathrm{~L}$ and the computed quantity of leachate was $34.90 \mathrm{~L}$ and the percentage of error for the unsaturated condition was $16.80 \%$ under estimation [percentage of error $=$ (observed computed)/observed] and the percentage of error in the peak was $36.80 \%$ [(3.80 - 5.20)/3.80] over estimation.

Figure 7 shows the measured and computed leachate volumes for saturated condition. The initial moisture condition for this simulation was constant throughout the depth of the column and equal to field capacity moisture content. From Fig. 7, it may be observed that the model results matched fairly with the experimental results. The volume of leachate collected from the solid waste through bottom outlets was started from the commencement of the experiment for both the model and experiment. It may be also noted that the rising limb of hydrograph of leachate computed leachate volume was less than the experimental results, and the peak value increased to $4.20 \mathrm{~L}$ instead of $3.60 \mathrm{~L}$. But in the recession limb portion of hydrograph,

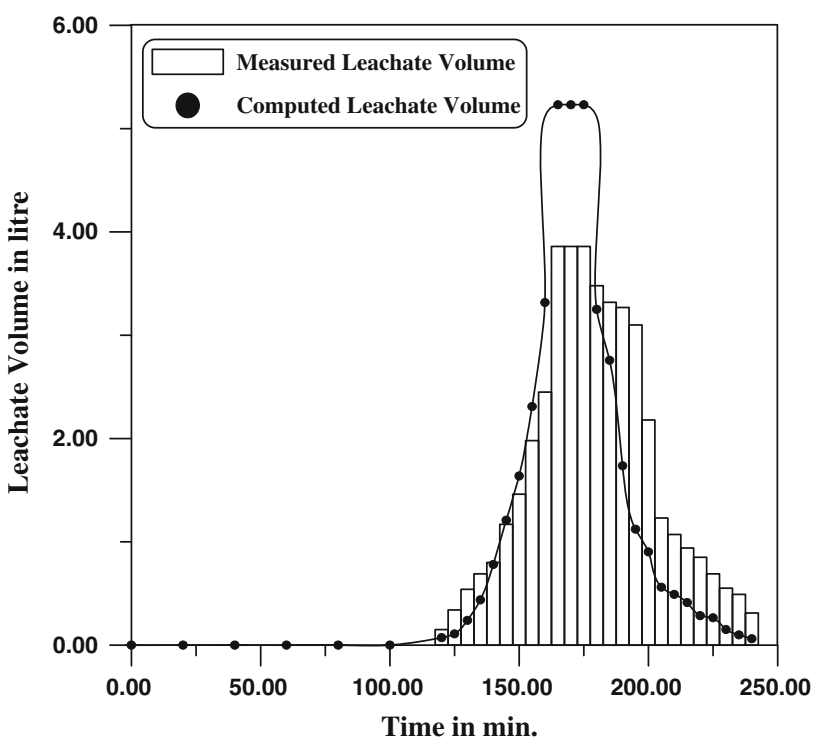

Fig. 6 Measured and computed leachate volumes for unsaturated condition

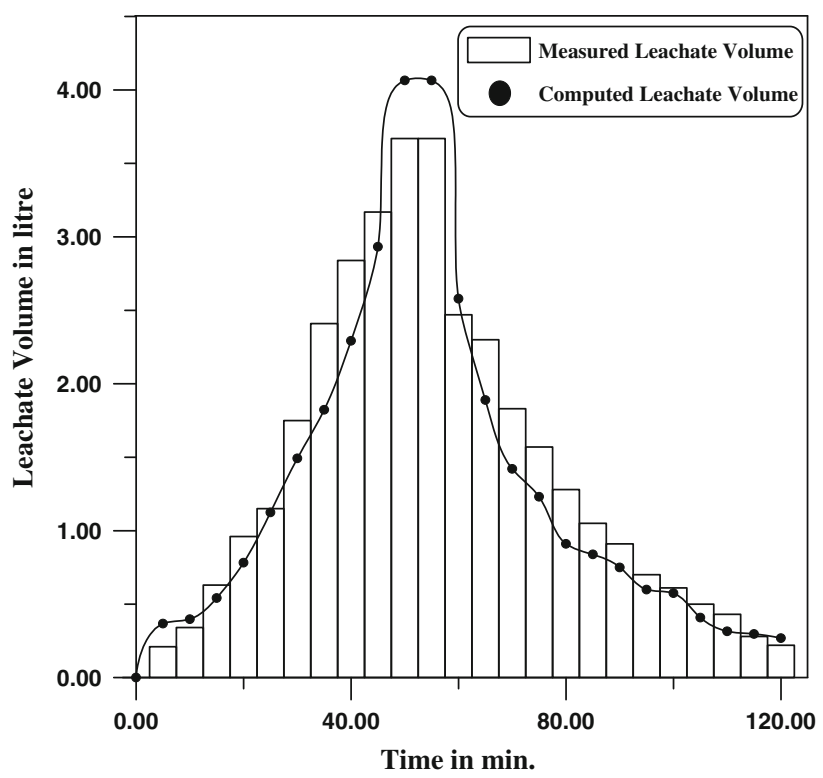

Fig. 7 Measured and computed leachate volumes for saturated condition

the computed leachate volume was less than the experimental observations. Similar to unsaturated condition, for saturated condition, the total time duration of collection of leachate for predicted and experimental work was same. Further, the observed quantity of leachate was $28.20 \mathrm{~L}$ and the computed quantity of leachate was $31.26 \mathrm{~L}$ and the percentage of error for the saturated condition was $10.86 \%$ (over estimation) and the percentage of error in the peak was $16.60 \%$ over estimation.

The Darcy's flux (analytical model) found (using the data from Table 5) for the present study and the previous 
studies are 0.00004121 (present study), 0.0001239 (Korfiatis et al. 1984) and $0.000000159 \mathrm{~m} / \mathrm{s}$ (Demetracopoulos et al. 1984), respectively. Further, the Reynolds number found for the present study and the previous studies are 1.305 (present study), 3.924 (Korfiatis et al. 1984) and 0.005 (Demetracopoulos et al. 1984), respectively. From the above results, it may be observed that the variation of these values depends on nature of the solid waste and these values will also change for different landfills and even for various locations within the same landfill. In addition, the variations are mainly due to the solid-waste composition, leachate flow, bio-decomposition of organic matter and compaction characteristics.

To validate the Darcy's law (details are explained in "Appendix"), the value of leachate flow per effective unit area of solid waste $[0.00003912 \mathrm{~m} / \mathrm{s}$ : Eq. (8)] obtained from experimental study was compared with leachate flow per effective unit area of solid waste $[0.00004121 \mathrm{~m} / \mathrm{s}$ : Eq. (9)] obtained from analytical model study. The results of analytical model study are well recognised with the results of experimental study. Further, the Reynolds number may also be computed using Darcy's law (Narasimhan 2004; Rahardyan et al. 2010) for both experimental and analytical model studies and the same was compared. In general, if the calculated Reynolds number using Darcy's flux is less than 1, then the flow is said to be laminar flow (Todd 1980; Arora 2009), but the value of Reynolds number may be extended up to 10 for the laminar flow in porous media according to the studies carried out by Ehigiator and Anyata 2008; Arora 2009; Alabi 2011. Since, the calculated Reynolds number for the experimental study [1.238: Eq. (10)] and analytical study [1.305: Eq. (10)] was less than 10, the Darcy's law used in experimental [Eq. (8)] and analytical model [Eq. (9)] studies is valid and the flow regime in solid-waste leachate column is confirmed as laminar flow. Further, the calculated Darcy's flux error difference $(5.07 \%)$ and Reynolds number error difference $(5.07 \%)$ between experimental study and analytical model studies showed, the formulated analytical model study is well recognised with experimental study.

\section{Conclusion}

The experimental investigations have been performed for eighteen combinations and details of two conditions (R1 and R2) were presented. The depth of solid-waste leachate column was reduced (runs R1 to R18) from 60 to $110 \mathrm{~mm}$ as a result of leaching of leachate and resettling of fine particles by incoming flowing water, bio-decomposition of organic matter in the solid waste and escaping of biogas from the solid waste to the atmosphere. The appearance of leachate flow from the bottom drainage outlets varied from
120 to $170 \mathrm{~min}$ after the commencement of the experiment for unsaturated condition and for with and without clay liner, where as there was no lag time for the collection of leachate for saturated condition. It was found that the quantity of leachate collected from the solid waste was non uniform through the various bottom outlets, side outlets and both bottom and side outlets condition. Similarly, time to peak of leachate flow varied. The analytical model was formulated using Darcy's law. The results of the analytical model study were compared with the results of the experimental study. The computed volume of leachate for unsaturated and saturated conditions was under and over estimation, respectively, with measured volume of leachate. Comparison results of leachate flow per effective unit area of solid waste using Darcy's law of experimental study is reasonable agreement with analytical model studies. Further, to validate the Darcy's law, the Reynolds number was calculated. Since, the calculated Reynolds number for the experimental and analytical studies was less than 10, the Darcy's law used in experimental and analytical model studies is valid and the flow regime in solidwaste leachate column is confirmed as laminar flow. Thus, the formulated analytical model equation for this study was able to predict the leachate volumes reasonably well.

\section{Appendix: validation of Darcy's laminar flow equation}

1. Leachate flow per effective unit area according to Darcy's law (Narasimhan 2004; Rahardyan et al. 2010) for experimental study is

$q=v=Q / A^{\prime}=Q / A \varepsilon$

where $q$ or $v$ is Darcy's flux through solid waste $=$ $0.00003912 \mathrm{~m} / \mathrm{s}, Q$ is discharge of the flow $=0.000003$ $\mathrm{m}^{3} / \mathrm{s}(21.6 \mathrm{~L} / 120 \mathrm{~min}$, Table 4$), A^{\prime}$ is effective crosssection area of flow $=0.07668 \mathrm{~m}^{2}, A$ is cross-sectional area of flow $=0.36 \mathrm{~m}^{2}\left(0.6 \times 0.6 \mathrm{~m}^{2}\right.$, Fig. 1), $\varepsilon$ is void ratio $=21.3 \%$.

2. Leachate flow per effective cross-sectional area according to Darcy's law (present study) for analytical model study is

$$
q=K_{\mathrm{s}}\left(\theta / \theta_{\mathrm{s}}\right)^{7.54}\left[1-2.27\left(\psi_{\mathrm{s}} / \theta_{\mathrm{s}}\right)\left(\theta_{\mathrm{s}} / \theta\right)^{3.27}(\partial \theta / \partial z)\right]
$$

where $q$ is Darcy's flux through solid waste $=$ $0.00004121 \mathrm{~m} / \mathrm{s}, K_{\mathrm{s}}$ is saturation hydraulic conductivity $=160.9 \mathrm{~mm} / \mathrm{h}=0.00004469 \mathrm{~m} / \mathrm{s}, \theta$ is moisture content at saturation condition and is equal to $\theta_{\mathrm{s}}, \theta_{\mathrm{s}}$ is saturation moisture content $=56.5 \%, \psi_{\mathrm{s}}$ is saturation suction pressure $=0.10 \mathrm{~m}$ of water, $\partial \theta$ is moisture content corresponding to void ratio $=21.3 \%, \partial z$ is thickness of 
the solid waste in experimental column $=1.1 \mathrm{~m}$, Reynolds number for experimental study and analytical model study is

$$
\operatorname{Re}=v D / v
$$

where Re is Reynolds number, (1) for experimental study, $\operatorname{Re}=1.2389$ and (2) for analytical model study, $\operatorname{Re}=$ 1.3051. $v$ is Darcy's flux through solid waste for experimental study $=0.00003912 \mathrm{~m} / \mathrm{s}$ [Eq. (8)] and Darcy's flux through solid waste for analytical model study $=$ $0.00004121 \mathrm{~m} / \mathrm{s}, \quad v$ is kinematic viscosity $=0.00000$ $0862 \mathrm{~m}^{2} / \mathrm{s}$ (at a temperature of $27^{\circ} \mathrm{C}$ ), $D$ is characteristics length $=$ volume of the particles to surface area of the solid-waste particles (solid-waste particles are assumed as sphere $)=(0.0273 \mathrm{~m})$.

3. The Darcy's flux error difference and the Reynolds number error difference between experimental study and analytical model study is

a. The error percentage for Darcy's flux $=$ $(0.00004121-0.00003912 / 0.00004121)$

$$
\times 100=5.07 \% \text {. }
$$

b. The error percentage for Reynolds number $=$ $(1.3051-1.2389 / 1.3051) \times 100=5.07 \%$.

\section{References}

Abdul Aziz H, Omran A, Zakaria WR (2010) $\mathrm{H}_{2} \mathrm{O}_{2}$ oxidation of pre coagulated semi aerobic leachate. Int J Environ Res 4(2): 209-216

Abdulhussain AA, Guo J, Liu ZP, Pan YY, Wisaam S, Al-Rekabi (2009) Review on landfill leachate treatment. J Appl Sci Res 5(5):534-545

Aderemi Adeolu O, Ada VO, Gbenga AA, Adebayo AO (2011) Assessment of groundwater contamination by leachate near a municipal solid waste landfill. Afr J Environ Sci Technol 5(11): 933-940

Agamuthu P, Al-Abdali SNA (2009) Physico-chemical treatment of Bukit Tagar sanitary landfill leachate using P-Floc775 and ferric chloride. Malays J Sci 28(2):187-195

Agatha A, Nwabueze (2011) Water quality and micro-organisms of leachate-contaminated pond. Am J Sci Ind Res 2(2):205-208

Alabi OO (2011) Validity of Darcy's law in laminar regime. Electron J Geotech Eng 16(A):27-40

Arora KR (2009) Soil mechanics and foundation engineering: (geotechnical 7th engineering) edition. Standard publishers distributors, Delhi

Berhe T, Wu W, Doanh T (2009) Leachate migration analysis of landfill in Bishkek, Kyrgyzstan. Geophysical research abstracts, vol 11, p 3008

Bicheldey TK, Latushkina EN (2010) Biogass emission prognosis at the landfills. Int J Environ Sci Technol 7(4):623-628

Campbell GS (1974) A simple method for determining unsaturated conductivity from moisture retention data. J Soil Sci 117(6): 311-314

Canter LW, Knox RC, Fairchild DM (1987) Groundwater quality protection. Lewis Publishers Inc, London
Christensen TH, Bjerg PK (2001) Biogeochemistry of landfill leachate plumes. Appl Geochem 16:659-718

Christensen TH, Kjeldsten P, Bjerge PL, Jensen DL, Christensen JB, Baun A, Albrechtsen HJ, Heron G (2001) Biogeochemistry of landfill leachate plumes. Appl Geochem 16(7-8):659-718

Dass P, Tamke GR, Stoffel CM (1977) Leachate production at sanitary landfill sites. J Environ Eng Proc ASCE 103(6):981-988

Demetracopoulos AC (1988) Overview of landfill bottom liner hydraulics. Water Resour Bul Am Water Resour Assoc 24(1): 49-56

Demetracopoulos AC, Korfiatis GP, Bourodimos EL, Nawy EG (1984) Modeling for design of landfill bottom liners. J Environ Eng Proc ASCE 110(6):1084-1098

Demetracopoulos AC, Sehayek L, Erdogan H (1986) Modelling leachate production from municipal landfills. J Environ Engg Proc ASCE 112(5):849-866

Ehigiator OA, Anyata BU (2008) Saturated hydraulic conductivity in a tropical alfisol in Southwest Nigeria. Environ Res J 2(2):70-75

Ehrig HJ (1984) Treatment of sanitary landfill leachate: biological treatment. Waste Manage Res 2:131-152

El-Fadel M, Findikakis AN, Leckie JO (1997) Environmental impacts of solid waste landfilling. J Environ Manage 50:1-25

Fenn DG, Henley KJ, Degree TV (1975) Use of the water balance for predicting leachate generation from solid waste disposal site: Rep S.W. 168. US Environmental Protection Agency, Wasington, DC, pp 8-11

Hamzeh AJ, Amir HM, Ramin N, Foorogh V, Ghasem AO (2009) Combination of coagulation-flocculation and ozonation processes for treatment of partially stabilized landfill leachate of Tehran. World Appl Sci 5:9-15

Iaconi CD, Ramadori R, Lopez A (2006) Combined biological and chemical degradation for treating a mature municipal landfill leachate. Biochem Eng J 31:118-124

Khanbilvardi RM, Ahmed S, Gleason PJ (1995) Flow investigation for landfill leachate (FILL). J Environ Eng Proc ASCE 121(1): $45-57$

Kjeldsen P, Barlaz MA, Rooker AP, Baun A, Ledin A, Christensen TH (2002) Present and long-term composition of MSW landfill leachate: a review. Crit Rev Env Sci Technol 32(4):297-336

Klute A (1952) A numerical method for solving the flow of water in unsaturated materials. J Soil Sci 73:105-116

Korfiatis GP, Demetracopoulos AC (1986) Flow characteristics of landfill leachate collection systems and liners. J Environ Eng Proc ASCE 112(3):538-550

Korfiatis GP, Demetracopoulos AC, Bourodimos EL, Nawy EG (1984) Moisture transport in a solid waste column. J Environ Eng Proc ASCE 110(4):780-796

Kulikowska D, Klimiuk E (2008) The effect of landfill age on municipal leachate composition. Bioresour Technol 99(13): 5981-5985

Maqbool F, Bhatti ZA, Malik AH, Pervez A, Mahmood Q (2011) Effect of landfill leachate on the stream water quality. Int J Environ Res 5(2):491-500

Metcalf and Eddy (1993) Waste water engineering treatment disposal reuse. Tata McGraw-Hill, New Delhi

Misra SH, Mani D (1993) Pollution through solid waste. Ashish Publishing House, New Delhi

Modi PN (1995) Irrigation water resources and water power engineering. Standard Book House, Delhi

Mor S, Ravindra K, Dahiya RP, Chandra A (2006) Leachate characterization and assessment of groundwater pollution near municipal solid waste landfill site. Environ Monit Assess 4:325-334

Murthy VNS (1992) A text book of soil mechanics and foundation engineering. Sai Kripa Technical Consultants, Bangalore 
Narasimhan TN (2004) Darcy's law and unsaturated flow. Vadose Zone J 3:1059

Ogundiran OO, Afolabi TA (2008) Assessment of the physicochemical parameters and heavy metals toxicity of leachates from municipal solid waste open dumpsite. Int J Environ Sci Technol 5(2):243-250

Oygard JK, Gjengedal E (2009) Uranium in municipal solid waste landfill leachate. Int J Environ Res 3(1):61-68

Ozturk I, Altinbas M, Koyuncu I, Arikan O, Gomec-Yangin C (2003) Advanced physico-chemical treatment experiences on young municipal landfill leachates. Waste Manage 23:441-446

Pankaj RM, Prakash BN (2011) Quantitative and qualitative assessment of municipal solid waste for Nagpur city. JERS 2(2):55-61

Perrier ER, Gibson AC (1980) Hydrologic simulation on solid waste disposal sites: EPA-SW-868. US EPA, Cincinnati

Rahardyan B, Dwirestiani R, Padmi T (2010) Determination of intrinsic permeability for packed waste of Indonesian solid waste. ITB J Eng Sci 42(2):137-150

Ranjan G, Rao ASR (2000) Basic and applied soil mechanics. New Age International (P) Ltd., New Delhi

Remson I, Fungaroli AA, Lawarence AW (1968) Water movement in an unsaturated sanitary landfill. J Sanit Eng Div Proc ASCE 94(2):307-317

Rodriguez J, Castrillon L, Maranon E, Sastre H, Fernandez E (2004) Removal of nonbiodegradable organic matter from landfill leachates by adsorption. Water Res 38:3297-3303

Saeedi M, Bazkiaei AR, Torkaman Z (2010) Insights in leaching characteristic assessment of solidified wastes using different leach tests. Int J Environ Res 4(3):455-462

Safari E, Ghazizade MJ, Shokouh A, Bidhendi GhRN (2011) Anaerobic removal of COD from high strength fresh and partially stabilized leachates and application of multi stage kinetic model. Int J Environ Res 5(2):255-270

Schroeder PR, Gibson AC, Smolen MD (1984) The hydrologic evaluation of landfill performance (HELP) model: documentation for version I, vol II. US Army Engineer Water Ways Experiment Station, Vicksburg, pp 14-20

Sivakumar D (1999) Solid waste leachate quantity and quality estimation: M. Tech project thesis. Department of Civil Engineering, Indian Institute of Technology Madras, Chennai

Sivakumar D, Thandaveswara BS (2004) Lumped landfill leachate production model for leachate flow. Hydrol J 27(1-2):103-116

Slomczyńska B, Slomczyński T (2004) Physico-chemical and toxicological characteristics of leachates from MSW landfills. Pol J Environ Stud 13(6):627-637

Tchobanoglous G, Theisen H, Eliassen R (1977) Solid wastes engineering principles and management issues. McGraw-Hill, New York

Thandaveswara BS, Sivakumar D (2004) Moisture distribution through solid waste landfills. IE(I) J-EN 84:63-69

Todd DK (1980) Groundwater hydrology, 2nd edn. Wiley, New York

Wong J (1977) The design of a system for collecting leachate from a lined landfill site. Water Resour Res 13(2):404-410

Yoshida M, Ahmed S, Nebil S, Ahmed G (2002) Characterization of leachate from Henchir El Yahoudia close landfill. Water Waste Environ Res 1:129-142

Zaman AU (2010) Comparative study of municipal solid waste treatment technologies using life cycle assessment method. Int $\mathbf{J}$ Environ Sci Tech 7(2):225-234

Zouboulis A, Chai X, Katsoyiannis I (2004) The application of bioflocculant for the removal of humic acids from stabilized landfill leachates. J Environ Manage 70:35-41 